\title{
Object position and Heavy NP Shift in Old Saxon and beyond
}

\author{
George Walkden \\ University of Manchester
}

\begin{abstract}
This paper investigates the position of 'heavy' nominal objects in Old Saxon and other Germanic languages. A new empirical study of Old Saxon is carried out and regression analysis performed, with information status, grammatical weight and case all serving as predictors. On the theoretical side it is argued that an analysis in terms of movement to specifier positions in a low left periphery goes some of the way towards capturing the observed facts, but still suffers from certain problems.
\end{abstract}

\section{Introduction ${ }^{1}$}

The factors conditioning the alternation between object-verb (OV) and verb-object (VO) orders in Old English (OE) have been the subject of a lot of attention in recent years (see Pintzuk 2002, 2005 and the references given there; Biberauer \& Roberts 2005, 2008, 2009; Wallenberg 2009, to appear; Taylor \& Pintzuk 2010, to appear). Initial investigation of the data revealed that information structure seemed to play a role in conditioning the alternation, leading naturally to the simple hypothesis that objects are postverbal iff they are new information (cf. e.g. Roberts 1997:412). Taylor and Pintzuk (2010, to appear), however, show that this hypothesis is false for OE, and that the mapping from surface constituent order to information structure must therefore be more complex than previously assumed; furthermore, they show that grammatical weight - how 'long' or 'heavy' the object is - plays a role. In this paper I investigate

1. Earlier versions of this paper were presented at the Workshop on Information Structure, Potsdam, December 2011, at the Second Workshop on Information Structure and Word Order Change, Oslo, June 2012, and at the 45th Annual Meeting of the Societas Linguistica Europaea, Stockholm, August 2012. I thank audiences at these events and reviewers of this paper for their comments, especially Kristin Bech, Kristine Eide, Roland Hinterhölzl, Svetlana Petrova and Christine Meklenborg Salvesen. Particular thanks go to Susan Pintzuk and Ann Taylor for inspiring the empirical part of this work, and for patiently responding to questions of detail. Any remaining blunders are entirely my responsibility. 
whether Old Saxon (OS), the closest attested contemporary relative of OE, patterns with $\mathrm{OE}$ in these respects - a question that is interesting not only for its own sake but also for the light it may shed on the diachrony of the West Germanic languages.

The paper is split into two key segments. Firstly, after laying out the theoretical background in Section 2 and methodology in Section 3, I present new data drawn from the OS Heliand, and discuss their relevance for analyses of the OV/VO alternation, in Section 4. The results indicate that with respect to the information structure and weight of objects OS can indeed be said to pattern with OE. Section 5 broadens the focus to processes of 'rightward movement'/Heavy NP Shift (HNPS) in Germanic as a whole, and deals with the question of how to analyse these. The starting point is the analysis presented by Wallenberg (2009, to appear), in which HNPS is viewed as a diachronically stable phenomenon involving movement of the object to SpecFocusP at the clausal left periphery followed by remnant movement of TP to a higher SpecTopicP. While the analysis is attractive in unifying 'rightward movement' cross-linguistically with leftward movement, within a uniformly head-initial approach to phrase structure à la Kayne (1994) and restrictive clausal cartography following Rizzi (1997), I present a number of empirical problems, which lead me to propose a slightly different alternative; my account maintains the assumptions of head-initiality and cartographic structure, but involves the 'low left periphery' above $v$ P rather than the clausal left periphery above CP. Section 6 discusses problems that remain for this account (and others within a cartographic framework), and concludes.

\section{Background}

A first glance at the syntax of $\mathrm{OE}$ "suggests a strong parallelism" between $\mathrm{OE}$ and modern Germanic verb-second (V2) languages such as Dutch and German (van Kemenade 1987:42), with V2 in main clauses, as in (1), and the verb in final position in subordinate clauses, as in (2).

(1) On twam pingum haefde God paes mannes saule gegodod in two things had God the man's soul endowed 'With two things had God endowed man's soul' (cocathom1,+ACHom_I, 1:184.161.166)

(2) hu he pat rice pam unrihtwisan cyninge aferran mihte how he the kingdom the unjust king deprive could 'how he could deprive the unjust king of the kingdom' (coboeth,Bo: 1.7.17.64)

This parallelism led van Kemenade (1987) to apply a variant of the classic den Besten (1977) analysis of V2 to OE, an insight which most modern analyses of the early West Germanic languages aim to maintain. 
Even in this early research it was recognized that there were complications, however. In main clauses the verb could be first, third, or later under certain circumstances, likely information-structurally conditioned: see e.g. Pintzuk (1993, 1999), Koopman (1995, 1997, 1998), Roberts (1996), Bech (1998, 2001), Haeberli (1999a, 1999b, 2002), Biberauer \& van Kemenade (2011), Bech \& Salvesen (this volume), Eitler \& Westergaard (this volume) among others. Main clauses will not feature further in this paper, but see Walkden (2012: Chapter 3; to appear) for discussion. The relative position of verb and object in the lower portion of the clausal hierarchy as evidenced most usually by subordinate clauses - has also engendered substantial discussion: see Pintzuk (1999, 2002, 2005), Roberts (1997), Fuß \& Trips (2002), Biberauer \& Roberts (2005, 2008, 2009); Wallenberg (2009, to appear); Taylor \& Pintzuk (2010, to appear); Haeberli \& Pintzuk (2012). This is the problem that the present paper will be concerned with.

Unlike modern standard German, OE was not exclusively OV but allowed various permutations of finite auxiliary, non-finite verb and object: see Pintzuk (2005: 117-119) for illustration of the range of variation permitted. The only logically possible permutation of these elements that is not attested is VOAux (see Biberauer, Holmberg \& Roberts 2010 for an attempted explanation of this fact, which appears to be just one case of a more general cross-linguistic exclusion). ${ }^{2}$ The challenge for analysts of $O E$ has been to account for all and only the attested orders, and this has proven difficult both

2. It is not strictly true that VOAux order is never found in Germanic. Pintzuk (2005:120) gives (i) from $O E$, and reports that three such examples can be found in the YCOE corpus (Taylor et al. 2003). In my own search of this corpus I have found the following four clear examples:

i. ... hu hie gedon ymbe pa menn hafdan how they done about the men had

'... how they had dealt with the men'

(cobede,Bede 5:11.416.25.4189; Pintzuk 2005: 120,8)

ii. ... pat he swa in toweardnesse ecelice ricsian mid Criste moste that he so in future eternally reign with Christ might $\therefore$ that he may thus in the future reign eternally in Christ' (cobede,Bede:3:21.248.21.2544)

iii. Gif hwylc broðor oft reedlice gepread for hwylcum gylte bið if a brother often explicitly chastised for a fault is

'If a brother is often explicitly chastised for a fault ...' (cobenrul,BenR:28.52.4.643)

iv. ... part he Criste healdan getrywlice sceolde that he Christ hold trustingly should '... that he should trustingly hold to Christ' (cochdrul,ChrodR:1:43.14.578) 
within a Kaynian head-initial framework and within a framework in which the order of heads with respect to their complements is permitted to vary. The head-parameter analysis as summarized in Pintzuk (2005) derives all the possibilities, and must only stipulate that VOAux is excluded. The Kaynian analysis of Biberauer and Roberts $(2005,2008,2009)$ fares similarly. ${ }^{3}$ Only the account of Wallenberg (2009) seems able to overcome these problems, though at the cost of assuming a monoclausal derivation for multi-verb clauses in OE, i.e. one in which auxiliaries are first Merged in functional projections above the lexical verb's $v$ P.

In the first part of this paper I abstract away from the precise details of the analysis, as do Taylor and Pintzuk (2010, to appear). The important question for present purposes is what conditions the alternation between the grammatical options. Fox (2000) and Reinhart (1995) have proposed that 'optional' operations are only permitted when they allow an interpretation that would not otherwise be available: in other words, 'an optional rule can apply only when necessary to yield a new outcome' (Chomsky 2001:34). If we accept that we should try to avoid positing interpretively vacuous optionality, at least as a methodological principle, then an account is needed for the different possibilities in OE. As mentioned in Section 1, one possible account that might initially seem consistent with the facts is a biconditional relationship between information status and object position, as stated in (3). ${ }^{4}$

There are six further, less clear examples (coaelhom,+AHom_27:74.3973; coblick,HomS_17_ [BlHom_5]: 59.88.735; coboeth,Bo:27.64.19.1200; comary,LS_23_[MaryofEgypt]:415.271; cowulf,WHom_4:83.154; cowulf,WHom_6:138.331). In all such examples the O element is not a nominal object of the verb but a PP or adverb. In view of their extreme rarity in the corpus, Pintzuk explicitly assumes that such examples were not grammatical in OE (2005: 120). Furthermore, at least for the Bede Examples (i) and (iii), the five extant manuscripts diverge in constituent order. In the case of (i), manuscript $T$ (upon which the edition used in the YCOE is based) and manuscript $C$ are the only ones that show VXAux ordering, with manuscripts $\mathrm{B}, \mathrm{Ca}$ and $\mathrm{O}$ displaying the more usual XVAux (Miller 1898: 524). It is notable that the scribe for this brief section of T is described by Miller (1890: xiv) as 'the most illiterate' of the five scribes. In the case of (iii), only T shows VXAux, with B, Ca, C and O all showing XVAux (Miller 1898:274). It is at least possible, then, that all VXAux examples in the YCOE are the result of scribal error.

3. Biberauer and Roberts (2005:35-36, Footnote 20) suggest that their analysis cannot derive VOAux. However, Haeberli (2008: 2003, Footnote 2) points out that VOAux can in fact be derived under their system, and can only be ruled out by stipulation.

4. Early analyses (e.g. Roberts 1997:412) predict (3) for OE. The analysis of Biberauer and Roberts $(2005,2008,2009)$ may appear to make this prediction, but only if it is assumed that auxiliary constructions in OE are monoclausal; if such constructions are assumed to be biclausal, involving selection of a non-finite TP by a finite $\mathrm{V}$, as in Biberauer and Roberts (2005: 15), then VO orders can be derived with or without focus. 
(3) Verb-Before-New Hypothesis

Given objects appear in OV configurations; new objects appear in VO configurations.

Appealing though this hypothesis is, Taylor and Pintzuk (to appear) show it to be false for $\mathrm{OE}$. If postverbal position is associated consistently with new information, as suggested by (3), this predicts that there should be a similar ratio of new to given objects in both AuxVO and VAuxO clauses. Taylor and Pintzuk (to appear) are able to falsify this: while the effect of information status on object position is statistically significant in VAux clauses, there appears to be no such effect in AuxV clauses. Accepting Taylor and Pintzuk's results, then, we are forced to posit a means of deriving VO order that is unrelated to the simple given/new object distinction.

The question that will be addressed in Sections 3 and 4 of this paper is whether a similar result can be obtained for Old Saxon. Along with OE and Old High German (OHG), OS is one of only three West Germanic languages to have a textual tradition dating back to the first millennium AD. Two main texts exist from this period: the Heliand, a gospel harmony written in alliterative verse of 5,968 lines, and fragments of a version of the Genesis story, also in verse. Both can be dated to the first half of the 9 th century. Syntactic studies are few and far between, especially within the generative framework (though see Erickson 1997; Linde 2009; Walkden 2012, to appear). The data for this paper are drawn from the Heliand, using the HeliCoPTER (Walkden 2011), a corpus of the Heliand manually annotated for syntactic properties at the clause level and based on the Behaghel (1948) edition.

OS, like OE, displays five of the six logically possible orderings of Aux, O, and V: only VOAux is unattested. Examples of each from subordinate clauses are given below; auxiliaries are underlined, objects are in bold, and non-finite verbs are de-italicized.

(4) OVAux:

huar he thea liudi tô lêdean scolde

where he the people to lead should

'where he should lead the people to'

(Heliand 4816)

(5) VAuxO:

that hie hebbian mugi cuningduomes namon

that he have may kingdom.gen name

'that he may have a kingdom's name'

(Heliand 5362-5363)

(6) AuxOV:

that sie sculun iro gode thionon

that they should their god serve

'that they should serve their god'

(Heliand 4459) 
(7) AuxVO:

that ênig liudeo ni scal farfolgan is friunde

that any people.GEN NEG shall follow his friend

'that no one shall follow his friend'

(Hcliand 1492-1493)

(8) OAuxV:

huô sia is gibodscip scoldin frummian

how they his message should accomplish

'how they should follow his teachings'

(Heliand 6)

The relevance of the research question is threefold. Firstly, a better understanding of Old Saxon syntax is desirable in and of itself. Secondly, replicating the study of Taylor and Pintzuk (2010, to appear), on a closely related language and using roughly the same methodology, would serve as a vindication of that methodology and indicate that their result is unlikely to be a freak one. Thirdly, it has implications for the historical development of West Germanic syntax. Lenerz (1984) suggests that something like (3), though false for OE, may be correct for OHG (see Hinterhölzl 2009 for further discussion). If this is the case, then OS, which occupies a phylogenetically and geographically intermediate position on the early West Germanic dialect continuum, may be able to help us decide whether the OHG situation or the OE situation is more original. This study will not be able to settle the question of whether OS patterns with OHG rather than OE, since the methodologies of work on the latter two languages are not directly comparable: whereas Taylor and Pintzuk (2010 to appear) adopt a quantitative perspective based on a given/new distinction, work on OHG so far has been largely qualitative (though cf. recently Sapp 2013) and based on the focus/background distinction. Nevertheless, a study that is at least comparable with previous research on OE will hopefully provide a starting point for research into this question.

\section{Methodology}

The methodology of the empirical part of this paper follows that of Taylor and Pintzuk (to appear) relatively closely; see their paper for more details. I first extracted all subordinate clauses ${ }^{5}$ containing all of the following:

5. Unlike Taylor and Pintzuk (to appear), I considered only subordinate clauses, in order to abstract away from any possible effect of clause type or verb-movement (on which see Walkden to appear). Disambiguating clausal status in OS is not straightforward, however (Somers \& Dubenion-Smith 2011), and it should be noted that classification as main or subordinate in the HeliCoPTER may be questioned in some cases. 
- A finite modal or auxiliary

- A non-finite verb ${ }^{6}$

- A nominal object that is not a (personal or demonstrative) pronoun

There are 312 such clauses in total. Of these, I further excluded all instances involving quantified $^{7}$ or negative objects (see Pintzuk \& Taylor 2006 on the behaviour of quantified objects in OE), as well as all instances of OAuxV and/or object-before-subject (for which it can be assumed that some other process of object scrambling/topicalization is at play; see Dreschler, this volume), leaving a total of 214 relevant clauses.

Annotation for information status was then carried out on the objects of the remaining clauses. Again, this closely follows the scheme used by Taylor and Pintzuk (2010, to appear), which is itself based on Birner (2006): see Table 1.

Table 1. Information status categorization (Birner 2006:45)

\begin{tabular}{lll}
\hline & Hearer-old: & Hearer-new: \\
\hline Discourse-old: & $\begin{array}{l}\text { Evoked: Identity/Elaborating } \\
\text { Inferrable (inferentially linked } \\
\text { and known to hearer) }\end{array}$ & $\begin{array}{l}\text { Bridging Inferrable } \\
\text { (inferentially linked, but not known to } \\
\text { hearer) }\end{array}$ \\
Discourse-new: & $\begin{array}{l}\text { Unused } \\
\text { (not inferentially linked, but } \\
\text { known to hearer) }\end{array}$ & $\begin{array}{l}\text { Brand-new } \\
\text { (not inferentially linked, and not known } \\
\text { to hearer) }\end{array}$ \\
\hline
\end{tabular}

Following Taylor and Pintzuk (2010 to appear), who expand on this classification, objects were marked as one of the following:

- Referentially new (Birner's 'Brand-new');

- New discourse referent (Karttunen 1976), i.e. a new referent that, unlike other 'referentially new' referents, can only be referred back to within a limited syntacticsemantic domain;

- 'Bridging' inferrable (Birner 2006), i.e. a referent which is inferentially linked to some given entity but not known to the hearer, e.g. an alienably possessed entity (see also Haug, Eckhoff \& Welo this volume);

'Elaborating' inferrable (Birner 2006), i.e. a referent which is inferentially linked to some given entity and which can be assumed to be known to the hearer, e.g. an inalienably possessed entity;

6. This does not include to-infinitives, as it is not clear that these were truly verbal in early West Germanic. For OE, Callaway (1913), Anderson (1993: 14) and Jarad (2003) express the view that these forms were essentially nominal, though see Los $(1998,2005)$ and Fischer et al. (2000:62) for a reappraisal.

7. Quantifiers excluded are ênig 'any' (6x), (sô) filo/manag '(so) many' (11x), sum 'some' (2x), bêđia 'both' (1x), mêr 'more' (3x), al 'all' (7x), gihuilik 'each' (4x), and uuiht 'anything' (10x). 
- Previously mentioned entities (within the last 30 lines);

- Situationally evoked entities;

- Shared/world knowledge (typically extremely generic objects such as manno barnun 'children of men' or dages lioht 'daylight').

For the purposes of the figures in the next section, the categories down to bridging infer rables are collapsed into the category of new, while the remaining categories from elaborating inferrables onwards are treated as given. ${ }^{8}$

A clear example of a given object, one that has previously been mentioned, is in (9).

(9) Context: Sie ... hêtun thar lêdien forđ ên uuîf ...

'They had a woman led forward' (Heliand 3840-3841)

Sie bigumun ina thô frâgon,... huat sie scoldin themu

they began him then ask what they should the.DAT

uuîbe duan

woman.DAT do

'They began to ask him what they should do with the woman'

(Heliand 3846-3847)

1

The woman is introduced in line 3841 , and referred back to six lines later; this second instance is therefore unambiguously classed as given. By contrast, the object in (10) is brand new:

(10) that thu ... gehuggean ni unili thana suâran balcon, the that you consider NEG will the.ACC heavy.ACC plank.ACC that

8. This scheme, adopted in its entirety, gives a relatively good data fit for OS, as the next section shows. Nevertheless, a few words of caution are in order on a conceptual level. Information status can for this type of study only be measured either in 'objective' terms, using measures such as coreference and occurrence within a fixed-size preceding segment (here 30 lines), or in 'hearer-subjective' terms, as information status from the perspective of the annotator, perhaps trying to put one's feet in the shoes of the prototypical/original reader of the text. However, the sentences we find in any corpus are the output (after production filters) of some speaker's grammar, and the speaker has no access to 'hearer-subjective' information, and presumably less access than the annotator to 'objective' information (speakers don't go back and count words). In other words, the speaker does not know in any absolute sense whether an entity is new to the hearer or to the discourse, but must rely on her/his own ('speaker-subjective') judgements. If information status is relevant to the grammar of a language as witnessed by texts, then, it must be 'speaker-subjective' information status and not 'objective' or 'hearer-subjective'; however, we have no access to this information. Any measure of information status in a corpus must in this sense be a highly imperfect proxy to the real object of study. 
thu an thinoro siuni habas

you in your eye have

'that you ... do not want to consider the heavy plank that you have

in your eye'

(Heliand 1704-1706)

Finally, (11) contains an example of a bridging inferrable, and (12) of an elaborating inferrable:

(11) that fiur êuuig, that thar gigareuuid uuard godes andsacun the fire eternal that there prepared becomes God's enemies.DAT 'the eternal fire that is prepared for God's enemies'

(Heliand 4421)

(12) thie hebbiad iro herta gihrênod

who have their hearts purified

'who have purified their hearts'

(Heliand 1315)

God is already (omni)present in the discourse in (11), but his enemies have not been mentioned and are not obviously known to the hearer. Bridging inferrables such as these are therefore treated as new information. In contrast, the fact that a person has a heart can be assumed by the hearer, and therefore iro herta in (12) is treated as given information. See Taylor and Pintzuk (this volume) on the utility of distinguishing these two types of inferrable.

Finally, annotation for grammatical weight was carried out. Following Taylor and Pintzuk (to appear), only open class words were counted, excluding for instance possessive pronouns and demonstratives/articles. Objects of four or more open class words were treated as a single category. Example (13) shows a single-word object; Example (14) a very long object (see also (10)).

(13) that uui ni môtun te themu hobe kêsures that we NEG must to the.DAT court.DAT emperor's

tinsi gelden

taxes.ACc pay

'that we must not pay taxes to the emperor's court'

(Heliand 5188-5189)

(14) Tho thiu magad habda githionod te thanke thiodcuninge when the maid had served to thank.DAT people-king.DAT

endi allumu themu erlskepie

and all.DAT the.DAT people

'When the maid had sufficiently served the king and all his people' (Heliand 2766-2768) 


\section{Object position: Results}

The first observation to be made relates to the proportions of VO and OV in AuxV and VAux clauses in the Heliand.

Table 2. Frequency of VO order by verb order in OE Orosits and OS Heliand

\begin{tabular}{lcccccccc}
\hline \multirow{2}{*}{ Text } & \multicolumn{3}{c}{ VAux } & & \multicolumn{3}{c}{ AuxV } \\
\cline { 2 - 3 } & $\mathrm{N}$ & of which VO & \% VO & & $\mathrm{N}$ & of which VO & \% VO \\
\hline Orosius (OL) & 66 & 3 & 5 & & 47 & 15 & 32 \\
Heliand (OS) & 96 & 18 & 19 & & 118 & 28 & 24 \\
\hline
\end{tabular}

While 'Taylor and Pintzuk (to appear, their Table 1) find that VO is significantly more common in AuxV than in VAux clauses in OE, this effect is not significant for OS. Table 2 compares data from Orosius, a typical OE text in this respect, with my data from the Heliand. The effect of relative ordering of auxiliary and non-finite verb is clearly significant for Orosius $(\mathrm{p}=0.0001)$, whereas it is not significant for the Heliand $(\mathrm{p}=0.4070)$. $^{9}$

\subsection{Information status}

The proportions of $\mathrm{VO}$ and $\mathrm{OV}$ in AuxV and VAux clauses by information status are given in Table 3; compare Taylor and Pintzuk's (to appear) Table 2.

Table 3. Frequency of VO order in VAux vs. AuxV clauses by information status in the Heliand

\begin{tabular}{lcccccccc}
\hline \multirow{2}{*}{ Info status } & \multicolumn{3}{c}{ VAux } & & \multicolumn{3}{c}{ AuxV } \\
\cline { 2 - 3 } & $\mathrm{N}$ & of which VO & \% VO & & $\mathrm{N}$ & of which VO & \% VO \\
\hline given & 75 & 10 & 13 & & 87 & 17 & 20 \\
new & 21 & 8 & 38 & & 31 & 11 & 36 \\
\hline
\end{tabular}

As in Taylor and Pintzuk's data, here we can see a difference between VAux and AuxV clauses: while in VAux clauses VO is clearly more frequent with new objects than with given objects, this is less salient for AuxV clauses. The result is significant at the 0.05 level for VAux $(p=0.0225)$ and not for AuxV $(p=0.0878)$. This difference between VAux and AuxV is not as clear as for OE, for which Taylor and Pintzuk report

9. All tests are two-tailed Fisher's exact tests unless otherwise stated. 
$\chi^{2}=14.6, p=0.0005$ for VAux and $\chi^{2}=2.27, p=0.132$ for AuxV. Nevertheless, the same asymmetry can be observed. Whether the difference in significance level between my results and those of Taylor and Pintzuk (to appear) reflects a genuine difference between OS and OE or is merely an artefact of the sample and testing is difficult to know; $\chi^{2}$ significance levels cannot, of course, be taken as an indicator of effect size (see e.g. Rietveld, van Hout \& Ernestus 2004: 356-358). ${ }^{10}$

As for $\mathrm{OE}$, then, we cannot assume that all postverbal objects are new in OS: (3) appears to be false for the Heliand. A weaker hypothesis, that the same proportions of given and new objects appear preverbally and postverbally, also cannot be upheld. For OE, Taylor and Pintzuk (to appear) take this to indicate that there are two distinct postverbal object positions, only one of which is strongly associated with new information status, and in VAux clauses only this one may be filled. I assume the same for OS; the analysis is spelled out more fully in Section 5. The remaining factors conditioning the OV/VO alternation - which has been shown to be a change in progress during the Old and Middle English periods: see van der Wurff $(1997,1999)$ and Pintzuk and Taylor (2006) - are still to be discovered.

\subsection{Case}

While case has been shown to have a significant effect on object position in Germanic, the precise effect differs between languages. Taylor and Pintzuk (to appear) report Dunbar (1979: 175) as finding for OHG that accusative objects are less likely to occur postverbally than genitive or dative objects, and Burridge (1993: 103) as finding the same for Middle Dutch. They themselves find no significant difference between accusatives and datives for $\mathrm{OE}$, but instead observe a significant difference between genitives and both accusatives and datives in VAux clauses $\left(\chi^{2}=33.6, p<0.0005\right.$; see their Table 3$)$, with genitive objects being more likely to occur in postverbal position than either of the others.

For the Heliand, case does indeed have an effect, but as for OE this is not significant in AuxV clauses (Yates' $\chi^{2}=3.327, \mathrm{p}=0.1895$ ), only in VAux clauses (Yates' $\left.\chi^{2}=17.611, p=0.0001\right)$. While there is no significant difference between accusatives and genitives (Yates' $\chi^{2}=0.109, p=0.7413$ ), dative objects occur postverbally with significantly greater frequency. ${ }^{11}$

10. A curious difference between my results and those of Taylor and Pintzuk (to appear) is with regard to the overall frequency of given vs. new objects in AuxV vs. VAux clauses, abstracting away from relative verb-object order. While there is a significant difference here for OE based on Taylor and Pintzuk's data $(\mathrm{p}<0.0001)$, there is no such difference for OS $(p=0.5226)$. The importance of this is unclear.

11. If datives and genitives are conflated as 'indirect objects', as in Dunbar and Burridge, then there is no significant difference between these and accusatives (Yates' $\chi^{2}=2.627, p=0.1051$ ). 
Table 4. Frequency of VO order in VAux vs. AuxV clauses by case in the Heliand

\begin{tabular}{|c|c|c|c|c|c|c|}
\hline \multirow[t]{2}{*}{ Case } & \multicolumn{3}{|c|}{ VAux } & \multicolumn{3}{|c|}{ AuxV } \\
\hline & $\mathrm{N}$ & of which VO & $\%$ VO & $\mathrm{N}$ & of which VO & $\%$ VO \\
\hline accusative & 75 & 11 & 15 & 73 & 15 & 21 \\
\hline genitive & 14 & 1 & 7 & 16 & 2 & 13 \\
\hline dalive & 7 & 6 & 86 & 29 & 11 & 38 \\
\hline
\end{tabular}

The extremely small numbers in some cells of Table 4 - e.g. only one postverbal genitive object, and only one preverbal dative object, in VAux clauses - make it difficult to have much confidence in these results. However, it is worth asking whether the differences in the results found by different researchers on different early Germanic languages might indicate that case is not itself responsible for the effect found, and that some other lurking variable might be at work here.

\subsection{Grammatical weight}

Within the class of nominals studied, Taylor and Pintzuk (to appear) use the number of open class words as a proxy for grammatical weight, following Szmrecsányi (2004). They find a significant effect for $O E$, measured as number of open class words, in both VAux and AuxV clauses (Fisher's exact test, $\mathrm{p}<0.0001$ for both; see their Table 4). In both VAux and AuxV clauses, the longer an object is, the more likely it is to be found postverbally. My data show the same trend.

Table 5. Frequency of VO order in VAux vs. AuxV clauses by object weight in the Heliand

\begin{tabular}{|c|c|c|c|c|c|c|}
\hline \multirow[t]{2}{*}{ Words } & \multicolumn{3}{|c|}{ VAux } & \multicolumn{3}{|c|}{ AuxV } \\
\hline & $\mathrm{N}$ & of which VO & $\% \mathrm{VO}$ & $\mathrm{N}$ & of which VO & $\% \mathrm{VO}$ \\
\hline 1 & 49 & 4 & 8 & 77 & 6 & 8 \\
\hline 2 & 38 & 10 & 26 & 21 & 11 & 52 \\
\hline 3 & ) & - & - & 10 & 2 & 20 \\
\hline $4+$ & 9 & 4 & 44 & 10 & 9 & 90 \\
\hline
\end{tabular}

The difference is clearly significant in AuxV clauses (Yates' $\chi^{2}=38.703$, $\mathrm{p}<0.0001, \mathrm{df}=3$ ), and significant in VAux clauses, albeit barely (Yates' $\chi^{2}=6.314$, $\mathrm{p}=0.0426, \mathrm{df}=2$ ). In both types of clause, three-word objects behave strangely: in 
AuxV clauses they are less commonly VO than one might expect, and in VAux clauses they are not found at all. ${ }^{12}$

\subsection{Strength of effect}

In addition to the tests carried out above, a logistic regression was carried out using Rbrul (Johnson 2009) in order to determine the strength of those effects that can be observed. The results are presented in Table 6 (compare Taylor \& Pintzuk's Table 5). Grey cells represent effects whose strength is not significant: as for Taylor and Pintzuk's OE data, while weight, information status and case are all significant for VAux clauses, only weight is significant for AuxV clauses.

Table 6. Results of multivariate analysis, effects in log odds

\begin{tabular}{llrr}
\hline Variable & Level & VAux & AuxV \\
\hline length (open) & per additional word & 0.982 & 1.216 \\
info status & given & -1.025 & -0.505 \\
& new & 1.025 & 0.505 \\
I case & accusative & -1.254 & -0.251 \\
& dative & 3.202 & 0.747 \\
& genitive & -1.949 & -0.496 \\
\hline
\end{tabular}

The log odds values, if negative, indicate a disfavouring effect on VO, and if positive indicate a favouring effect on VO with respect to the mean. For instance, in VAux clauses, new objects have a log odds value of 1.025 , indicating that this context favours VO. The odds ratio is $e^{1.025}=2.787$, indicating that the odds of a VAux clause being VO are increased by $(2.787-1) * 100=179 \%$ if the object is new. By contrast, the odds ratio for given objects is $e^{-1.025}=0.359$, indicating that the odds of a VAux clause being VO are decreased by $(1-0.359)^{\star} 100=64.1 \%$ if the object is old. ${ }^{13}$

The picture given by Table 6 is remarkably similar to that gleaned from Taylor and Pintzuk (to appear) for OE; cf. also Hróarsdóttir (2000), who shows that grammatical weight is the decisive factor determining object position in Old Icelandic. The

12. Since three is the number of the Holy Trinity, perhaps this is for numerological reasons (Rathofer 1962)!

13. Nagelkerke pseudo- $R^{2}$ values are 0.459 for VAux and 0.388 for AuxV, roughly indicating that the factors included in the model explain $46 \%$ and $39 \%$ respectively of the variation attested in the data. 
main differences are (a) that the effects of different values for case are different (see Section 4.2), and (b) that, in contrast to OE, the effect of weight is stronger in AuxV clauses than in VAux clauses. It is not clear what is responsible for either of these differences.

The strongest factor, and the only one to be found significant in both VAux and AuxV clauses, is grammatical weight. One possible explanation for this is that what started out as a purely information-structurally driven positional alternation, similar to (3) above, has been (at least partially) reinterpreted as a weight condition (Roland Hinterhölzl, p.c.). Alternatively, the complex combination of weight and informationstructure that we observe in this text (and in OE) may always have been present in Germanic object positioning; lacking data for earlier stages, it is impossible to be sure.

\section{Heavy NP Shift in Old Saxon and beyond: Analysis}

So far I have said nothing about the derivation of clauses involving 'new' objects. Taylor and Pintzuk (to appear), at least partially for expository reasons, represent this as right-adjunction to TP. However, the derivation/representation of (and motivation for) such adjunction is not the focus of their paper. Within modern theory, an influential line of research following Kayne (1994) has argued that the assumption that all trees are right-branching, or at least are linearized in this form, makes stronger (and more accurate) predictions than the more flexible directionality-based approach. ${ }^{14}$ Furthermore, adjunction itself has been rejected by some theorists as too unconstrained, and replaced by a fixed universal 'cartography' of functional projections with dedicated specifier positions (Bayer 1996; Cinque 1999). If we adopt either of these assumptions, right-adjunction is ruled out in principle.

Whether or not these assumptions are on the right track, it is worth investigating how the early Germanic facts can be captured under them. Individual analyses have tried to account for some of these phenomena without rightward movement or adjunction: Biberauer and Roberts $(2005,2008,2009)$, for instance, assume that focalized objects remain in situ and are spelled out after all other material, due to a particular implementation of phase theory, Radical Spellout. However, unified analyses of this type of phenomenon are rare, which is surprising given that as apparent instances of rightward movement they present a serious problem for the strong Kaynian thesis

14. One modern approach that rejects Kayne's (1994) Linear Correspondence Axiom is that of Abels and Neeleman (2008). However, this approach relies on the assumption that movement must be leftward, which is equally incompatible with a derivation involving rightadjunction of a moved argument to TP. 
at first sight. A welcome exception is the analysis of Wallenberg (2009, to appear), to which I now turn, following the presentation in Wallenberg (to appear).

\subsection{A unified theory of Heavy NP Shift}

Wallenberg aims for a unified analysis of apparent rightward movement processes affecting NPs/DPs across Germanic (which he labels 'Heavy NP Shift' or HNPS, following Ross 1967) that is both antisymmetry-friendly and cartography-friendly. Specifically, he argues in favour of the following claims:

(15) HNPS is a unified phenomenon across Germanic, both synchronically and diachronically.

(16) HNPS involves leftward movement of the 'heavy' object, followed by leftward remnant movement of the rest of the clause.

(17) HNPS is movement to a dedicated specifier position associated with its own interpretation.

(18) HNPS is movement to the left periphery of the clause.

The specific structure proposed is given in (19), illustrated with a Modern English example. (I abstract away from irrelevant levels of structure; the use of trace notation is not intended to imply a theoretical commitment to traces.) TopP and FocP are leftperipheral functional projections dedicated to topics and foci respectively, as defined by Rizzi (1997).

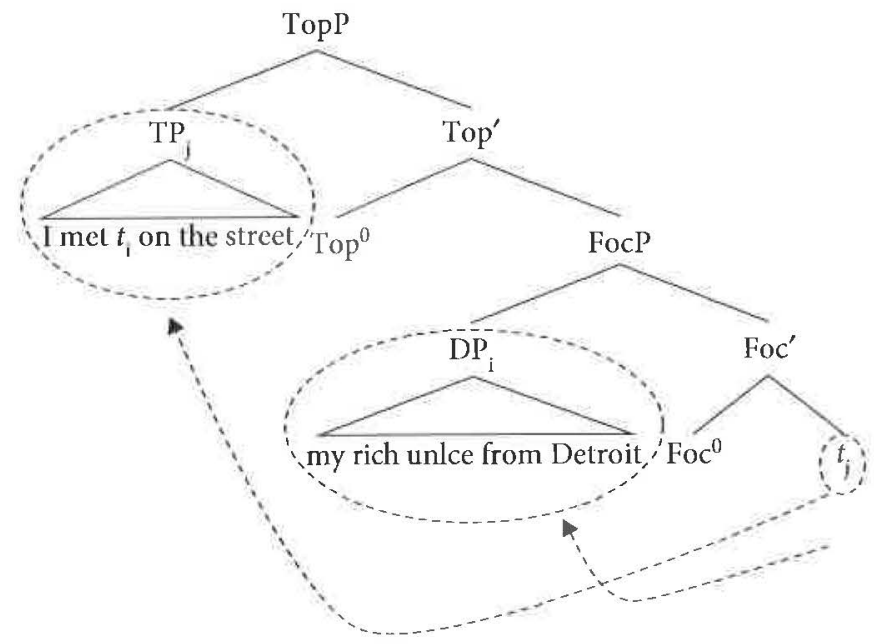

The proposal is attractive in unifying a range of data from across Germanic, including early West Germanic, Yiddish, and Pennsylvania German, and in its compatibility with restrictive theories of structure-building. In what follows I therefore adopt 
proposals (15)-(17). ${ }^{15}$ I differ only in suggesting an alternative to (18), the proposal that the left periphery of the clause is involved in HNPS. In the next subsection I present four arguments against this proposal.

\subsection{Heavy NP Shift does not involve the clausal left periphery}

That HNPS involves some sort of $\mathrm{A}^{\prime}$-movement is relatively clear: for instance, it licenses parasitic gaps, as Wallenberg (to appear) demonstrates. However, at least four arguments militate against the left periphery of the clause being the destination.

Firstly, the left-peripheral FocP is usually thought of as being related to identificational rather than information (or presentational) focus, in the terms of Kiss (1998). While an element under identificational focus represents the exhauslive subset of the set of contextually given situations for which a predicate phrase can potentially hold, ${ }^{16}$ elements under information focus are simply non-presupposed (i.e. new) information; see Eide and Sitaridou (this volume) for further discussion of the typology of foci. Belletti (2004) argues that identificational focus is associated with the left periphery cross-linguistically, and that information focus is associated with a different position. If this view is correct, then we would expect constituents that have undergone HNPS to be identificational foci. We can test this by evaluating the ability of constituents that are semantically excluded from being identificational foci to undergo HNPS. Kiss $(1998: 252)$ argues that some-phrases and universal quantifiers fall into this category, since they cannot occur in focus position in Hungarian or in the cleft construction in English. Some-phrases and universal quantifiers are, however, fully grammatical in Modern English HNPS, as illustrated by (20) and (21), and quantified DPs appear to be available in OE and OS HNPS too, as illustrated by (22) $-(25) \cdot .^{17}$

(20) if I met on the street someone from Bound for Glory or No Remorse they would most likely kick my ass (http://www.xcatalystx.com/board/viewtopic.php?f=2\&t=2562\&p=21819; last accessed 11th May 2012)

(21) we contemplated in silence all that we had experienced that night (Corpus of Contemporary American English, Davies 2008-)

15. However, in Section 6 I will discuss some remaining problems for assumptions (16) and (17).

16. Though see Kiss (1998:268-271) for proposed parametric variation between the identificational foci of different languages.

17. The OS examples are of postverbal subjects rather than objects, but the default assumption must surcly be that HNPS is insensitive to grammatical relations. 
(22) pe God gegearwod hafo eallum pam, pe hine andradað that God prepared has all.DAT those.DAT that him fear 'that God has prepared for all those who fear him' (YCOE, Taylor et al. 2003; cobenrul,BenR:7.24.2.351)

(23) pat he him sendan sceolde gif him swa gepuht ware, sume that he him send should if him so thought were some eawfreste munecas pious monks 'that he should send him, if he were so inclined, some pious monks' (coaelive,+ALS_[Maur]:53.1530)

(24) sô that uuiten ni mag ênig mannisc barn so that know NEG may any human child 'so that no human child may know that' (Heliand 4298-4299)

(25) that thea gesehan mugin alla gelico that DEM see may all.Nom alike 'that all alike may see that' (Heliand 1407-1408)

If constituents that have undergone HNPS are not identificational foci, then it is less appealing to analyse them as having moved to the clausal left periphery. ${ }^{18}$ Among my OS examples, at least, the referentially new objects in VAuxO clauses, e.g. (5) and (11), seem like good candidates for information focus, but not for identificational focus.

A second problem relates to the availability of the left periphery in subordinate clauses. It has been proposed for Modern English that in certain classes of subordinate clause it is impossible to front arguments to the left periphery, on the basis of data like (26) and (27) (Haegeman \& Ürögdi 2010: 118; Haegeman 2010:629). ${ }^{19}$

(26) *John regretted that [that film he went to see].

(27) *If [these exams you don't pass], you won't get the degree.

18. The assumption that information focus may not occur in the clausal left periphery is not entirely uncontroversial: counterexamples have been argued to exist in e.g. Russian (Bailyn 2003), Sicilian (Cruschina 2006), Old Spanish (Sitaridou 2011) and Latin (Danckaert to appear).

19. The precise account for these data varies: Hacgeman (2003), for instance, proposes that these clauses have truncated left peripheries, while in Haegeman (2010) a new account based on locality is suggested. Under either account the compatibility of HNPS with these contexts is problematic for the clausal left periphery theory of HNPS. 
IINPS does not pattern with argument fronting in this respect in Modern English, as illustrated by (28) as well as (19) above.

(28) John regretted that [he met on the street his rich uncle from Detroit].

As for earlier Germanic, the large number of examples of subordinate clause HNPS adduced by Taylor and Pintzuk (to appear) for OE and in this paper for OS indicate that there is no restriction on HNPS in subordinate clauses here either. If HNPS does not pattern with processes of argument fronting that unambiguously target the left periphery, then this is an argument against it being treated as such a process.

Another prediction made by the clausal-left-periphery account of INPS is that it should be incompatible with questions. Rizzi (1997:290-291) claims that there is a unique structural focus position, and that due to their semantics foci are incompatible with wh-operators in main interrogatives: 'focalized constituents and question operators compete for the same position and cannot co-occur' (1997:298). However, HNPS in Modern English is compatible with questions, as in (29) and (30).

(29) Who met on the street my rich uncle from Detroit?

(30) When did you meet on the street my rich uncle from Detroit?

This possibility is tricky to test for OE and OS due to the rarity of VAux order in main interrogatives, and I have not been able to find any corpus examples for Modern English either, but the grammaticality judgement seems clear. ${ }^{20}$

Finally, and relatedly, the clausal-left-periphery account of HNPS is inventive in turning the left periphery of the clause into the right periphery, yet is incompatible with accounts that assume that the left periphery in early Germanic is active in other ways in main clauses, e.g. Roberts (1996), Hinterhölzl and Petrova (2009), Walkden (2012, to appear) and van Kemenade and Milićev (2012). In such accounts, the distribution of topics and subjects, e.g. in Old English, is attributed to a syntactically highly active CP layer. It could be that these accounts are barking up the wrong tree; nevertheless, given the other three arguments against the involvement of the clausal left periphery in HNPS, it is worthwhile to seek an alternative.

\subsection{Heavy NP Shift involves the 'low left periphery'}

Such an alternative is provided by the 'low left periphery'. In a series of publications, Belletti $(2001,2004)$ has argued for an information-structural layer of discourse-related

20. Later work by Rizzi (2001) does assume a separate projection for wh-elements, WhP, lower than FocP. This poses less of a problem for Wallenberg's (to appear) account, but the fact that constituents that have undergone HNPS do not pattern with other foci still needs to be explained. 
projections above the $\nu \mathrm{P}$ and below the rest of the TP/IP layer. Furthermore, she has explicitly argued that this projection hosts information foci in the sense of Kiss (1998), rather than identificational foci, which must move to the clausal left periphery. I propose that HNPS involves movement to this position followed by remnant movement of $v \mathrm{P}$ to the specifier of the topic position above it, as illustrated by (31). As can be seen, the structure is virtually identical, simply transposed down the clause. Assumptions (15)-(17) are maintained. ${ }^{21}$

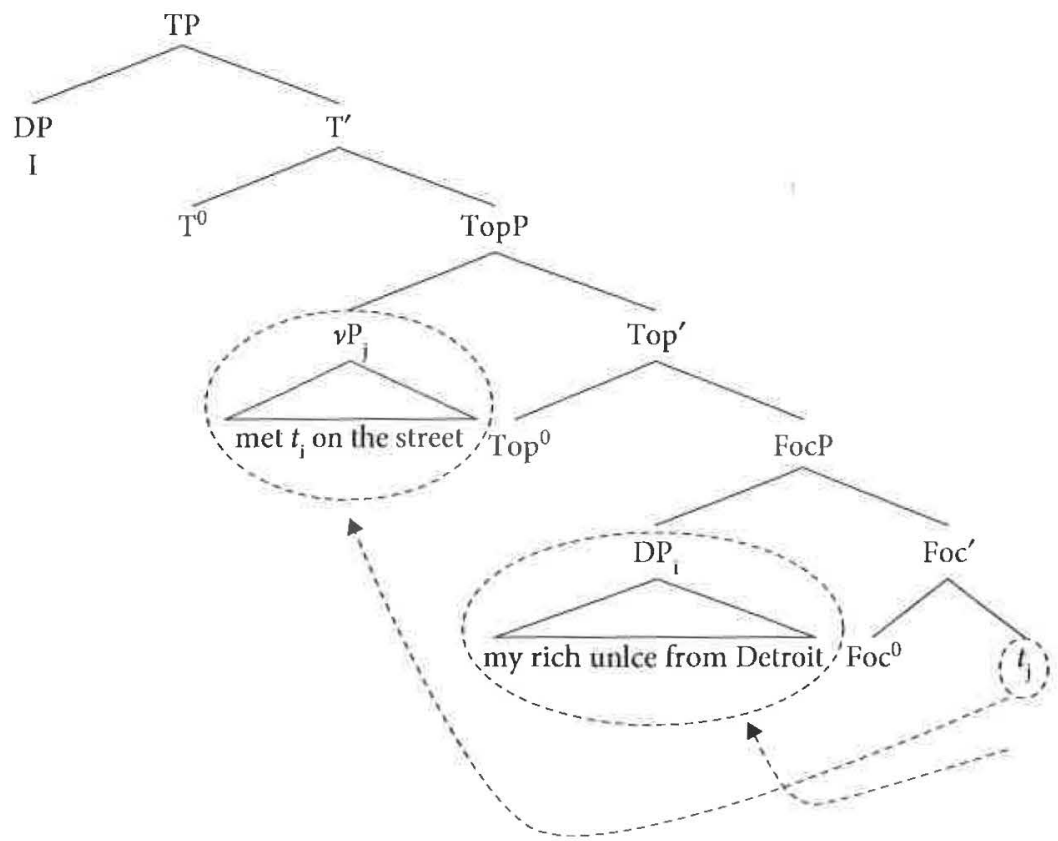

This analysis straightforwardly overcomes the problems raised in the previous subsection. First, if low foci are merely new information, then the compatibility of universal quantifiers and some-phrases with HNPS follows. Second, the 'low left periphery' is predicted to be present, and available, in subordinate clauses, making the correct predictions. Third, information foci can co-occur with interrogatives, as they are not in competition with $w h$-phrases syntactically or semantically. Fourth, there is no conflict between this account and theories that assume a more active clausal left periphery in early Germanic, since the peripheries involved are different.

21. Wallenberg (to appear) considers the low left periphery analysis, but suggests that the fact that the second movement (i.e. low remnant movement to SpecTopP) is 'unmotivated' constitutes an argument against it. Given that this movement is equally unmotivated in the clausal-left-periphery analysis, I do not consider this a particular problem for the low left periphery approach. 
The analysis also straightforwardly derives the attested word order variation in the earlier Germanic languages. I assume, with Biberauer and Roberts (2005, 2008, 2009), that a monoclausal derivation for multi-verb clauses in early Germanic is untenable, as the auxiliary-like and modal-like elements in these languages share many properties with full verbs and therefore should not be analysed as first Merged in $T^{\text {() }}$ (Lightfoot 1979; Warner 1993). A basic Old Saxon clause like (6) is analysed as in (32).

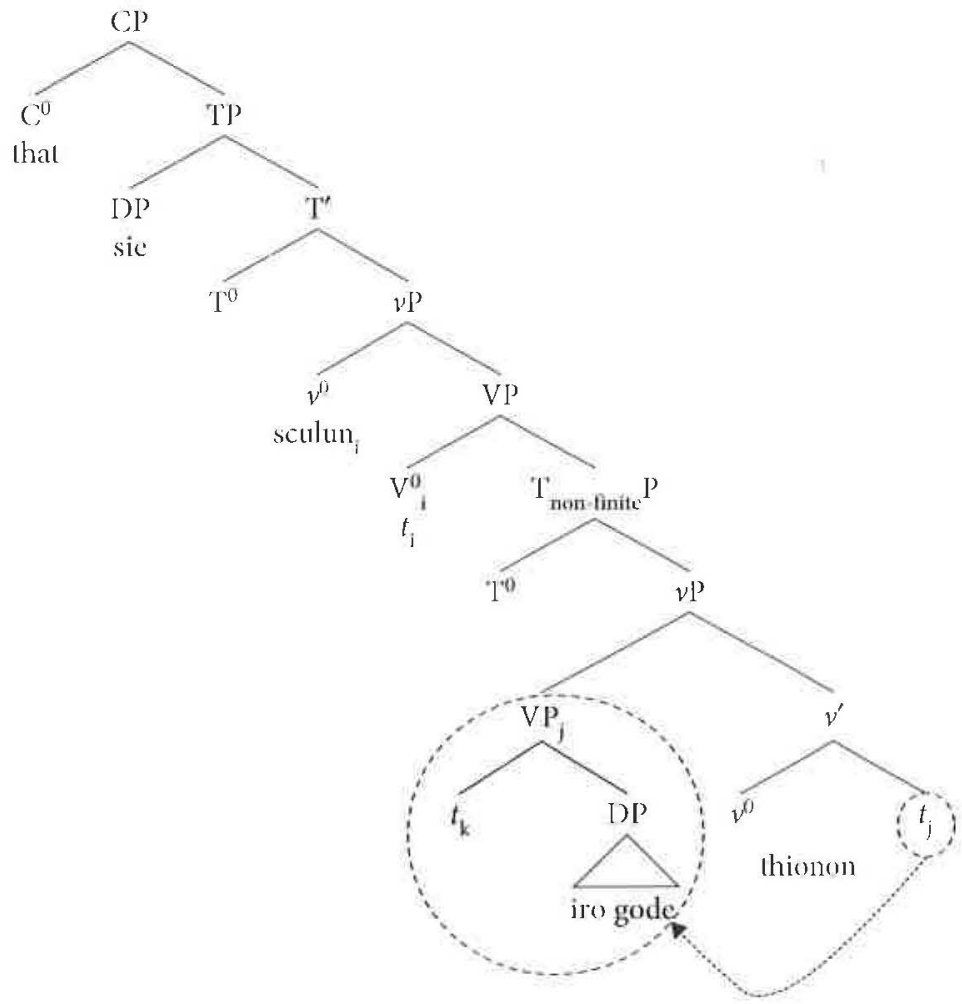

Both the auxiliary and the non-finite verb head their own VP, and both move to their own $v^{0}$. (Intermediate positions have been omitted for expository clarity.) First a nonfinite TP is constructed, which is selected by the finite verb (see Biberauer \& Roberts 2005). Either VP may move to its own SpecvP (under a Kaynian system, this is the equivalent of Taylor and Pintzuk's non-information-structural base-generated OV). In (32), the lower VP has moved to the lower SpecvP, yielding AuxOV order. If the higher VP also moves to the higher SpecvP, this would yield OVAux order, as in (4). If neither VP moves, this yields AuxVO order, as in (7).

So far, nothing has been said about information structure, and there is no way in the system of deriving VAuxO, as in (5). This is where the low left periphery comes in. 


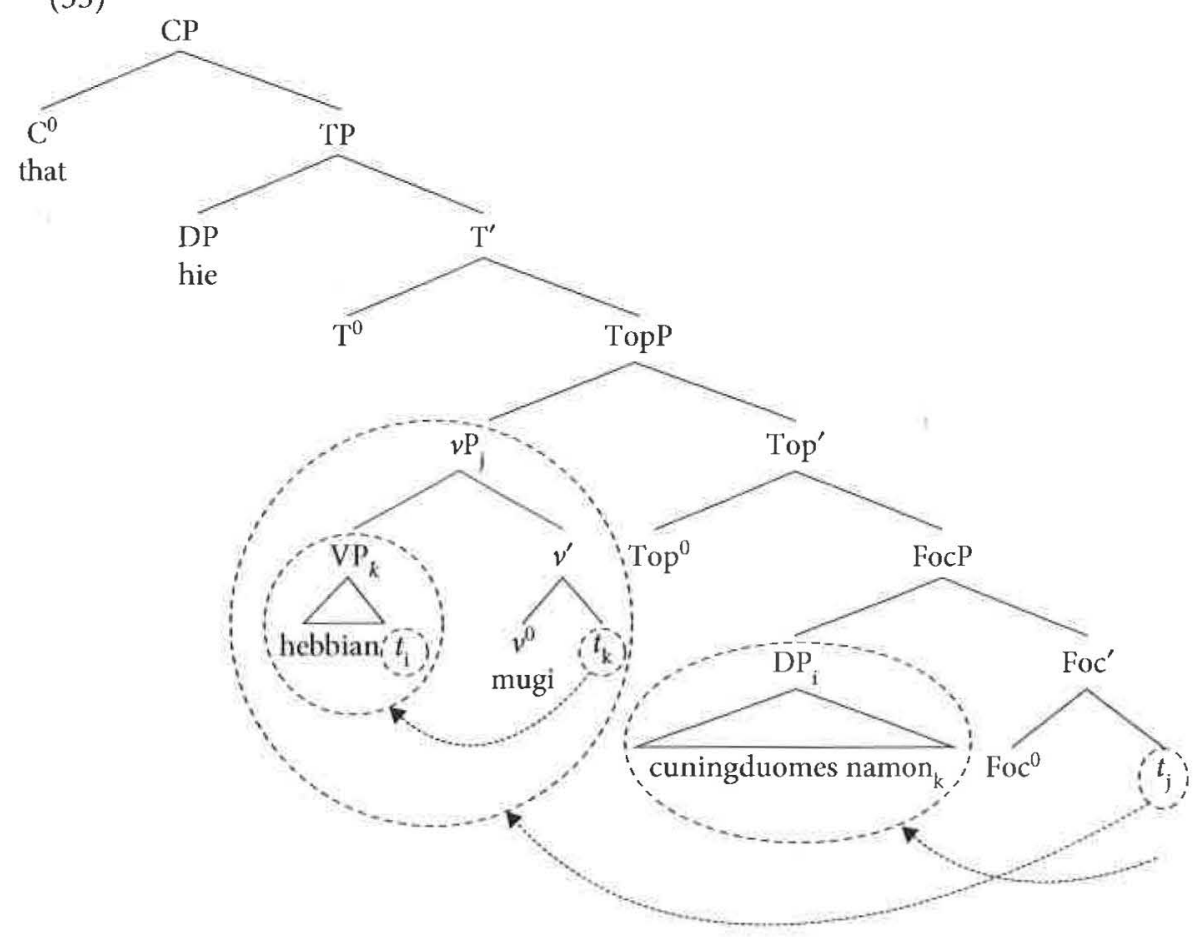

Here the higher VP is fronted to SpecvP. The new object may then move to SpecFocP, after which the entire remnant (higher) $v \mathrm{P}$ is fronted to SpecTopP. The movements of VP to Spec $v$ P, new objects to SpecFocP and/or $v \mathrm{P}$ to Spec'TopP are available in both the finite and the non-finite TP. In (33) any movements in the non-finite TP are rendered string-vacuous by the fact that all possible movement options are taken in the finite TP. ${ }^{22}$ Similar proposals involving the low left periphery have been invoked by Poletto (2006) for Old Italian and Salvesen (2011) for Old French. This proposal straightforwardly accounts for the fact that the effect of information status is stronger in VAux clauses than in AuxV clauses: whereas in AuxV clauses postverbal objects can be derived either by movement to SpecFocP or in situ, in VAux clauses they can only be derived by movement to SpecFocP.

22. Note that this means there are in principle two low SpecFocP positions: one in the non-finite TP, one in the finite TP. This means that Wallenberg's (to appear) diachronic argument against his own clausal-left-periphery-based account of HNPS is not a problem for the analysis presented here, as there are two potential landing sites for new objects. Like Wallenberg (to appear) I simply stipulate a PF filter barring VOAux (which this system is otherwise capable of deriving); for a more interesting account of this typological gap, see Biberauer, Holmberg \& Roberts (2010). 


\section{Conclusion and remaining problems}

In this paper I have shown (i) that OS to a large extent behaves like OE with regard to the information status of postverbal objects, as far as can be determined, and (ii) that a theory of HNPS in the spirit of Wallenberg (2009, to appear) but involving the 'low left periphery' comes close to accounting for the distribution of these objects. I now consider a few potential problems for this approach.

Firstly, the approach outlined in 5.3 runs into a problem if we assume that the Left Branch Condition (Ross 1967) - a ban on extraction from left branches - is general, since we predict that the fronted $\nu \mathrm{P}$ in the low SpecTopP should be a strong island, a prediction that is clearly false as shown by the presence of the subject (originally $\nu$ P-internal) in SpecTP. The account of Wallenberg (to appear) also suffers from this problem, as shown by the grammaticality of (34).

(34) Who did you say $t_{\mathrm{i}}$ met on the street your rich uncle from Detroit?

The problem may be illusory, though, as there are independent reasons to believe that the Left Branch Condition is not universal (see Bošković 2005 and Biberauer, Holmberg \& Roberts 2010 inter alia).

Secondly, and perhaps most importantly, the correlation between new information status and postverbal position is not absolute. This presents a problem for any approach that seeks to motivate derivations involving HNPS in terms of its interpretive effects. One could argue that the measures used to detect information status are not sensitive or accurate enough, or that the exact interpretive effects associated with HNPS need to be refined; there are too many variables to be sure. It may be that the correct way to approach the question is in terms of focus/background rather than given/new; this study does not consider, for instance, the possibility of given but nevertheless (identificationally) focalized items, nor the possibility of focus on a constituent larger than the object, for instance the VP. A simple given/new distinction was adopted for this study only because it is easy to operationalize and ensures comparability with the work of Taylor and Pintzuk. However, similar issues have arisen again and again in corpus-based information-structural investigations of HNPS. Bies (1996), for instance, in a study of right-peripheral objects in Early New High German, finds small numbers of examples of preverbal objects with narrow focus (roughly equivalent to 'new information' in our approach) and postverbal objects without narrow focus. Taylor and Pintzuk (to appear) find that even in VAux clauses, where the only possible derivation for postverbal objects is via HNPS, only $20.5 \%$ of objects are actually new. Similarly, in my Table 3 I found that only $38.1 \%$ of postverbal objects in the Heliand are new information. 
Even more worrying for an interpretation-based approach to HNPS - necessarily including all cartographic accounts - is the fact that, for English, grammatical weight has consistently been shown to be a better predictor of object position than information status (see Wasow \& Arnold 2003; Taylor \& Pintzuk to appear, and the references cited there). In addition to the quantitative data given in Table 5, suggestive examples exist:

(35) that thu hêr antkennien scalt craft drohtines, the mikilon that you here recognize shall strength lord's the great maht godes power God's

'that you shall here recognize the Lord's strength, the great power of God' (Heliand 4088-4089)

Here the object is an elaborating inferrable, and hence not brand new. The problem that this effect poses for syntactic theory and the architecture of the grammar cannot be overestimated, whether it is understood in terms of syntactic (processing) complexity or in terms of phonological heaviness. If syntactic complexity is the key factor, then under the assumption that 'grammars can't count', and that derivation proceeds locally, such effects are predicted not to exist. ${ }^{23}$ If phonological heaviness is the key factor, things are nearly as bad, since the Minimalist architecture of the grammar either assumes that phonological features are added after syntax or adopts a 'sealed suitcase' approach in which phonological features are passed through the derivation but the syntax is insensitive to them (see Scheer 2011). The 'sealed suitcase' assumption would have to be relaxed, as in the work of Holmberg (2000) and Hinterhölzl (2009), in order to account for this data. Another, rather desperate option is to view HNPS as a post-syntactic operation (cf. Biberauer \& Roberts 2005: 19), in which case its potential interpretive effects, and its ability to license parasitic gaps, are unexplained.

Approaches such as that of Wallenberg (2009, to appear) and the one adopted above, then, where Heavy NP Shift is conceptualized cartographically as movement to a dedicated syntactic position, must represent an oversimplification of a complex situation, the resolution of which is more important to linguistic theory than it may appear at first sight.

23. Unless some sort of production bias is at work to create the observed corpus distribution. But that would not account for the virtual unacceptability of (i):

(i) ??*I met on the street my uncle. 


\section{References}

Abels, Klaus \& Neeleman, Ad. 2008. Universal 20 without the LCA. Ms, CASTL/UCL.

Anderson, John. 1993. Parameters of syntactic change: A notional view. In Historical Linguistics: Problems and Perspectives, Charles Jones (ed.), 1-42. London: Longman.

Bailyn, John. 2003. Does Russian scrambling exist? In Word Order and Scrambling, Simin Karimi (ed.), 156-176. Oxford: Blackwell.

Bayer, Josef. 1996. Directionality and Logical Form: On the Scope of Focusing Particles and whin-situ. Dordrecht: Kluwer.

Bech, Kristin. 1998. Pragmatic factors in language change: XVS and XSV clauses in Old and Middle English. Folia Linguistica Historica 19: 79-102.

Bech, Kristin. 2001. Word Order Patterns in Old and Middle English: A Syntactic and Pragmatic Study. Ph.D. dissertation, University of Bergen. 〈https://bora.uib.no/handle/1956/3850〉

Behaghel, Otto. 1948. Heliand und Genesis, 6th edn. Halle: Max Niemeyer.

Belletti, Adriana. 2001. Inversion as focalization. In Subject Inversion in Romance and the Theory of UG, Aafke Hulk \& Jean-Yves Pollock (eds), 60-90. Oxford: OUP.

Belletti, Adriana. 2004. Aspects of the low IP area. In The Cartography of Syntactic Structures, Vol. 2: The Structure of IP and CP, Luigi Rizzi (ed.), 16-51. Oxford: OUP.

den Besten, Hans. 1977. On the interaction of root transformations and lexical deletive verbs. Ms, University of Amsterdam.

Biberauer, Theresa, Holmberg, Anders \& Roberts, Ian. 2010. A syntactic universal and its con! sequences. Ms, University of Cambridge.

Biberauer, Theresa \& van Kemenade, Ans. 2011. Subject positions and information-structural diversification in the history of English. Catalan Journal of Linguistics 10: 17-69.

Biberauer, Theresa \& Roberts, Ian. 2005. Changing EPP parameters in the history of English: Accounting for variation and change. English Language and Linguistics 9: 5-46.

Biberauer, Theresa \& Roberts, Ian. 2008. Cascading parameter changes: Internally-driven change in Middle and Early Modern English. In Grammatical Change and Linguistic Theory: The Rosendal Papers [Linguistik Aktuell/Linguistics Today 113], Thórhallur Eythórsson (ed.), 79-114. Amsterdam: John Benjamins.

Biberauer, Theresa \& Roberts, Ian. 2009. The return of the Subset Principle: A diachronic perspective. In Historical Syntax and Linguistic Theory, Paola Crisma \& Giuseppe Longobardi (eds), 58-74. Oxford: OUP.

Biberauer, Theresa \& Walkden, George (eds). To appear. Syntax over Time: Lexical, Morphological and Information-structural Interactions. Oxford: OUP.

Bies, Ann Elizabeth. 1996. Syntax and Discourse Factors in Early New High German: Evidence for Verb-final Word Order. MA dissertation, University of Pennsylvania.

Birner, Betty. 2006. Inferential relations and noncanonical word order. In Drawing the Boundaries of Meaning: Neo-Gricean Studies in Pragmatics and Semantics in Honor of Laurence R. Horn [Studies in Language Companion Series 80], Betty Birner \& Gregory Ward (eds), 31-51. Amsterdam: John Benjamins.

Bošković, Željko. 2005. On the locality of left branch extraction and the structure of NP. Studia Linguistica 59: 1-45.

Burridge, Kate. 1993. Syntactic Change in Germanic [Current Issues in Linguistic Theory 89]. Amsterdam: John Benjamins.

Callaway, Morgan. 1913. The Infinitive in Anglo-Saxon. Washington DC: Carnegie. 
Chomsky, Noam. 2001. Derivation by phase. In Ken Hale: A Life in Language, Michael Kenstowicz (ed.), 1-53. Cambridge MA: The MIT Press.

Cinque, Guglielmo. 1999. Adverbs and Functional Heads: A Cross-linguistic Perspective. Oxford: OUP.

Cruschina, Silvio. 2006. Informational focus in Sicilian and the left periphery. In Phases of Interpretation, Mara Frascarelli (ed.), 363-385. Berlin: Mouton de Gruyter.

Danckaert, Lieven. To appear. The decline of Latin left-peripheral presentational foci: Causes and consequences. In Biberauer \& Walkden (eds), to appear.

Davies, Mark. 2008-. The Corpus of Contemporary American English: 425 million words, 1990-present. 〈http://corpus.byu.edu/coca/〉 (11 May 2012).

Dunbar, Richard. 1979. Discourse Pragmatics and Subordinate Clause Word Order in German: An Explanation of Related Main Clause Phenomena in German and English clauses. Ph.D. dissertation, University of Wisconsin, Madison.

Erickson, Jon. 1997. Some observations on word order in Old Saxon. In Sprache im Fokus: Festschrift für Heinz Vater zum 65. Geburtstag, Christa Dürscheid, Karl Heinz Ramers \& Monika Schwarz (eds), 95-105. Tübingen: Max Niemeyer.

Fischer, Olga, van Kemenade, Ans, Koopman, Willem \& van der Wurff, Wim. 2000. The Syntax of early English. Cambridge: CUP.

Fox, Danny. 2000. Economy and Semantic Interpretation. Cambridge MA: The MIT Press.

Fuß, Eric \& Trips, Carola. 2002. Variation and change in Old and Middle English: On the valid-

1 ity of the Double Base Hypothesis. Journal of Comparative Germanic Linguistics 4: 171-224.

Haeberli, Eric. 1999a. Features, Categories and the Syntax of A-positions. Ph.D. dissertation, University of Geneva.

Haeberli, Eric. 1999b. On the word order 'XP-subject' in the Germanic languages. Journal of Comparative Germanic Linguistics 3: 1-36.

Haeberli, Eric. 2002. Inflectional morphology and the loss of V2 in English. In Syntactic Effects of Morphological Change, David Lightfoot (ed.), 88-106. Oxford: OUP.

Haeberli, Eric. 2008. Review of Roberts, Ian. 2007. Diachronic Syntax. Oxford: OUP. Lingua 118: 1998-2007.

Haeberli, Eric, \& Pintzuk, Susan. 2012. Revisiling verb (projection) raising in Old English. In Grammatical Change: Origins, Nature, Outcomes, Dianne Jonas, John Whitman \& Andrew Garrett (eds), 219-238. Oxford: OUP.

Haegeman, Liliane. 2003. Conditional clauses: External and internal syntax. Mind and Language 18: $317-339$.

Haegeman, Liliane. 2010. The internal syntax of adverbial clauses. Lingua 120: 628-648.

Haegeman, Liliane \& Ürögdi, Barbara. 2010. Referential CPs and DPs: An operator movement account. Theoretical Linguistics 36: 111-152.

Hinterhölzl, Roland. 2009. The role of information structure in word order variation and word order change. In Information Structure and Language Change: New Approaches to Word Order Variation in Germanic, Roland Hinterhölzl \& Svetlana Petrova (eds), 45-66. Berlin: Mouton de Gruyter.

Hinterhölzl, Roland \& Petrova, Svetlana. 2009. From V1 to V2 in West Germanic. Lingua 120: 315-328.

Holmberg, Anders. 2000. Scandinavian stylistic fronting: How any category can become an expletive. Linguistic Inquiry 31: 445-483.

Hróarsdóttir, Porbjörg. 2000. Word Order Change in Icelandic: From OV to VO [Linguistik Aktuell/Linguistics Today 35]. Amsterdam: John Benjamins. 
Jarad, Najib I. 2003. The Old English to-infinitive: Its status and recategorisation. Journal of Language \& Linguistics 2: 57-104.

Johnson, Daniel E. 2009. Getting off the GoldVarb standard: Introducing Rbrul for mixed effects variable rule analysis. Language o Linguistics Compass 3: 359-383.

Karttunen, Lauri. 1976. Discourse referents. In Syntax and Semantics, 7: Notes from the Linguistic Underground, James D. McCawley (ed.), 363-385. New York NY: Academic Press.

Kayne, Richard S. 1994. The Antisymmetry of Syntax. Cambridge MA: The MIT Press.

van Kemenade, Ans. 1987. Syntactic Case and Morphological Case in the History of English. Dordrecht: Foris.

van Kemenade, Ans \& Tanja Milićev. 2012. Syntax and discourse in Old and Middle English word order. In Grammatical Change: Origins, Nature, Outcomes, Dianne Jonas, John Whitman \& Andrew Garrett (eds), 219-238. Oxford: OUP.

Kiss, Katalin É. 1998. Identificational focus vs. information focus. Language 74: 245-273.

Koopman, Willem. 1995. Verb-final main clauses in Old English prose. Studia Neophilologica 67: $129-144$.

Koopman, Willem. 1997. Another look at clitics in Old English. Transactions of the Philological Society 95: 73-93.

Koopman, Willem. 1998. Inversion after single and multiple topics in Old English. In Advances in English Historical Linguistics, Jacek Fisiak \& Marcin Krygier (eds), 135-149. Berlin: Mouton de Gruyter.

Lenerz, Jürgen. 1984. Syntaktischer Wandel und Grammatiktheorie: Eine Untersuchung an Beispielen aus der Sprachgeschichte des Deutschen. Tübingen: Max Niemeyer.

Lightfoot, David. 1979. Principles of Diachronic Syntax. Cambridge: CUP.

Linde, Sonja. 2009. Aspects of word order and information structure in Old Saxon. In Information Structure and Language Change: New Approaches to Word Order Variation in Germanic, Roland Hinterhölzl \& Svetlana Petrova (eds), 367-389. Berlin: Mouton de Gruyter.

Los, Bettelou. 1998. The rise of the to-infinitive as verb complement. English Language and Linguistics 2: 1-36.

Los, Bettelou. 2005. The Rise of the to-infinitive. Oxford: OUP.

Miller, Thomas. 1890. The Old English Version of Bede's Ecclesiastical History of the English People. London: Trübner.

Miller, Thomas. 1898. A Collation of Four MSS. of the Old English Version of Bede's Ecclesiastical History of the English People. London: Kegan Paul, Trench \& Trübner.

Pintzuk, Susan. 1993. Verb seconding in Old English: Verb movement to Infl. The Linguistic Review 10: 5-35.

Pintzuk, Susan. 1999. Phrase Structures in Competition: Variation and Change in Old English Word Order. New York NY: Garland.

Pintzuk, Susan. 2002. Verb-object order in Old English: Variation as grammatical competition. In Syntactic effects of Morphological Change, David Lightfoot (ed.), 276-299. Oxford: OUP.

Pintzuk, Susan. 2005. Arguments against a universal base: Evidence from Old English. English Language and Linguistics 9: 115-138.

Pintzuk, Susan \& Taylor, Ann. 2006. The loss of OV order in the history of English. In The Handbook of the History of English, Ans van Kemenade \& Bettelou Los (eds), 249-278. Oxford: Blackwell.

Poletto, Cecilia. 2006. Parallel phases: a study on the high and low left periphery of Old Italian. In Phases of Interpretation, Mara Frascarelli (ed.), 261-294. Berlin: Mouton de Gruyter. 
Rathofer, Johannes. 1962. Der Heliand: Theologischer Sinn als tektonische Form. Köln: Böhlau.

Reinhart, Tanya. 1995. Interface strategies. OTS Working Papers in Linguistics. Utrecht: Univer sity of Utrecht.

Rietveld, Toni, van Hout, Rocland \& Ernestus, Mirjam. 2004. Pitfalls in corpus research. Computers and the Humanities 38: 343-362.

Rizzi, Luigi. 1997. The fine structure of the left periphery. In Elements of Grammar, Liliane Haegeman (ed.), 281-337. Dordrecht: Kluwer.

Rizzi, Luigi. 2001. On the position 'inl(errogative)' in the left periphery of the clause. In Current Studies in Italian Syntax: Essays Offered to Lorenzo Renzi, Guglielmo Cinque \& Giampaolo Salvi (eds), 267-296. Amsterdam: Elsevier.

Roberts, Ian. 1996. Remarks on the Old English C-system and the diachrony of V2. In Language Change and Generative Grammar [Linguistische Berichte, Sonderheft 7], Ellen Brandner \& Gisela Ferraresi (eds), 154-164. Opladen: Westdeutscher Verlag.

Roberts, Ian. 1997. Dircctionality and word order change in the history of English. In Parameters of Morphosyntactic Change, Ans van Kemenade \& Nigel Vincent (eds), 397-426. Cambridge: CUP.

Ross, John Robert. 1967. Constraints on Variables in Syntax. Ph.D. dissertalion, MIT.

Salvesen, Christine Meklenborg. 201 1. Stylistic Fronting and Remnant Movement in Old French. In Romance Languages and Linguistic Theory 2009. Selected Papers from 'Going Romance', Nice 2009, Janine Berns, Haike Jacobs \& Tobias Scheer (eds), 323-342. Amsterdam: John Benjamins.

Sapp, Christopher D. 2013. OHG subordinate clauses: A continuation of Proto-Germanic word order. Paper presented at Historical Syntax of German: Typological Perspectives, Bamberg, May 2013.

Scheer, Tobias. 2011. A Guide to Morphosyntax-phonology Interface Theories: How Extraphonological Information is Treated in Phonology since Trubetzkoy's Grenzsignale. Berlin: Mouton de Gruyter.

Sitaridou, Ioanna. 2011. Word order and information structure in Old Spanish. Catalan Journal of Linguistics 10: 159-184.

Somers, Katarina \& Dubenion-Smith, Shannon. 2011. Disambiguating clausal status in the Old Saxon Heliand. Ms, Queen Mary University London.

Szmrecsányi, Benedikt. 2004. On operationalizing syntactic complexity. In Le poids des mots. Proceedings of the 7 th International Conference on Textual Data Statistical Analysis, Gerard Purnelle, Cédrick Fairon \& Anne Dister (eds), 1032-1039. Louvain-la-Neuve: Presses universitaires de Louvain.

Taylor, Ann \& Pintzuk, Susan. 2010. Object position and information structure in Old English: an experiment in annotation. Paper presented at the Symposium on the History of English Syntax, York, May 2010.

Taylor, Ann \& Pintzuk, Susan. To appear. Verb order, object position and information status in Old English. In Biberauer \& Walkden (eds), to appear.

Taylor, Ann, Warner, Anthony, Pintzuk, Susan \& Beths, Frank. 2003. York-Toronto-Helsinki Parsed Corpus of Old English Prose. 〈http://www-users.york.ac.uk/ lang22/YcoeHome1.htm)

Walkden, George. 2011. HeliCoPTER (Heliand Corpus: A Partially Tagged Excel Resource). $\langle$ http://personalpages.manchester.ac.uk/stafl/george.walkden/helicopter/〉 (11 May 2012).

Walkden, George. To appear. Verb-third in early West Germanic: A comparative perspective. In Biberauer \& Walkden (eds), to appear. 
Walkden, George. 2012. Syntactic Reconstruction and Proto-Germanic. Ph.D. dissertation, University of Cambridge.

Wallenberg, Joel C. 2009. Antisymmetry and the Conservation of c-command. Ph.D. dissertation, University of Pennsylvania.

Wallenberg, Joel C. To appear. Antisymmetry and Heavy NP Shift across Germanic. In Biberauer \& Walkden (eds), to appear. (lingBuzz/001402)

Warner, Anthony. 1993. English Auxiliaries: Structure and History. Cambridge: CUP.

Wasow, Thomas, \& Jennifer Arnold. 2003. Post-verbal constituent ordering in English. In Determinants of Grammatical Variation in English, Günter Rohdenburg \& Britta Mondorf (eds), 119-154. Berlin: Mouton de Gruyter.

Wurff, Wim van der. 1997. Deriving object-verb order in late Middle English. Linguistics 33, 485-509.

Wurff, Wim van der. 1999. Objects and verbs in modern Icelandic and fifteenth-century English: A word order parallel and its causes. Lingua 109, 237-265. 